which is of great value, is really only a throw-back to the method of 'shifting cultivation' and should have a far wider application than north-west Germany. The old-type shifting cultivation is being utilized in India and Burma, under its burmese name taungya, by the forest officer to produce new crops of some of the more valuable species of timber trees; the practice is applicable to Africa and elsewhere in the tropics. But Wittich's work introduces a further most promising step to the problem of a world shortage of food. For the permanent forest areas of the world, which for various reasons it is imperative to conserve, can nevertheless be used for the growing of food crops for a pre-arranged number of years at the end of a forest rotation, and then the land can be returned to permanent forest. Such a system should substantially increase the amount of land available at any one time for agriculture.

\section{West African Gold Coast Timbers}

A smar.I handbook of Gold Coast timbers was first published in 1941; it proved of great utility to officers of the Forest Department and others concerned and was soon out of print. Since then, considerable progress has been made both in the assessment of the forest resources of the country and in the development of the timber trade. To meet a growing demand, it was decided to publish a new edition, a work undertaken by D. Kinloch and W. A. Miller, of the Gold Coast Forest Department ("Gold Coast T'imbers." Revised Edition. Pp. xii+39; Takaradi : Government Printing Department ; $1 s .6 d$.). Thanks are accorded to the Director of the Princes Risborough Forest Products Laboratory for assistance. The closed-forest zone of the Gold Coast occupies approximately one-third of the entire territory and has an area of some 30,000 square miles. The remaining northern two-thirds consists of the savannaforest zone, the forest resources of which are of purely domestic interest. The timber wealth of the country is concentrated in the closed-forest zone, of which it is estimated that some 16,000 square miles are still under forest; the remainder has been converted to agriculture, which continues to destroy an estimated 300 square miles of forest every year. The forest is not uniform in type throughout, there being a gradual transition from the south-west corner in a general north-easterly direction, and this transition is intimately connected with rainfall, though other local factors occur. Two types occur : the tropical semi-evergreen rain forest of the south-west corner, and the tropical mixed deciduous forest covering some ninety per cent or more of the whole zone. Sub-types are proposed, and a number of species described for which the booklet should be consulted. The information given in this new edition is almost entirely the work of the Forest Department and includes considerable additional data provided by enumeration surveys and records of the Forest Products Research Laboratory, Princes Risborough. War-time departmental experience in milling and utilization has also proved of great assistance.

\section{Proceedings of the Bihar Academy of Agricultural Sciences}

The first number of the Proceedings of the Bihar Academy of Agricultural Sciences has now been published. In view of the importance of agriculture in India to-day, this new journal should be a great asset, for research results, particularly those relating to local crops and climatic conditions, must be available to all concerned if progress is to be made on sound scientific lines. The subjects discussed in the first number are very varied, but in each case the emphasis is laid on the practical aspect of the problem. Among the biological papers are those on inter-varietal hybridization in Luffa acutangula and its economic significance, and studies in the production of carbon dioxide in stored wheat infested by Sitophilus granaria L. and S. oryzoe L. Soil and manurial problems are represented by a description of the Bihar soils, followed by an account of the results from a large number of field experiments carried out on cultivators' plots throughout the State. The benefit from the application of nitrogenous and phosphatic manures has been clearly demonstrated, and interest in their use so stimulated that appreciable increases in yields may be expected in many districts. The importance of statistics is evidently recognized, for the accuracy of field experiments is discussed in a further paper on the size and shape of plots in wheat trials. T'hree numbers of the journal will be published annually and these will be available free to members of the Academy; to others the annual subscription is Rs. 10. All communications should be addressed to the Secretary of the Academy, Agricultural Research Institute, P.O. Sabour (Bihar), India.

\section{Newspaper Libraries in Great Britain}

THe Library Association has published a pamphlet, entitled "Newspaper Libraries", by J. Lewis (No. 11 in the series ; pp. $76 ; 1952$. 7s., or $5 s$. to members), which outlines first the functions of such libraries in Great Britain and then describes the types of material contained in a newspaper library and the arrangement, classification and filing of such material. Some account is given of the news indexes maintained and indexing practice in newspaper libraries, of the methods used for the care and preservation of general and special material, and of the formal and informal co-operation which exists with other libraries. The pamphlet includes both a bibliography and index, and these facilitate reference to much information which may assist the technical or scientific librarian on occasion, as well as those whose needs are more general.

\section{Manchester Museum : Annual Report for 1950-51}

THE annual report of the Manchester Museum for the year ending July 1951 (pp. 28 ; from the Museum, Manchester; 1952) gives an account of continued progress in all departments. The housing of study and reserve collections has presented many problems, though by extensive movement of cupboards and cases a more orderly arrangement has been attained. The proper storage of collections involves classification, which is also an essential preliminary to cataloguing. One essential function of museums is research, and in this connexion it is interesting to note the large number of papers written by members of the staff during the year.

\section{Fifth Empire Mining and Metallurgical Congress}

The fifth Empire Mining and Metallurgical Congress will be held in Australia during April 12-May 23, 1953, and afterwards in New Zealand. The Congress will afford an opportunity for mining engineers, metallurgists, scientific workers, engineers and others concerned with the mining and metallurgical industries to meet and discuss technical 